\title{
Perennial peanut hay nutritive value
}

\begin{abstract}
The aim of this work was to determine the contents of dry matter (DM), neutral detergent fiber (NDF), acid detergent fiber (ADF), crude protein (CP), mineral matter (MM), and lignin and to evaluate the in vitro dry matter degradability (IVDMD) of Arachis pintoi hay. Five beds with $3.99 \mathrm{~m}^{2}$ each were used and nine cuts were made after 40days intervals during a year. Mean NDF, ADF, MM, lignin and IVDDM were submitted to the ScottKnott test $(\mathrm{p} \leq 0.05)$. DM and lignin did not vary statistically, the values of NDF, ADF, $\mathrm{MM}$ and IVDDM differed $(\mathrm{p} \leq 0.05)$ ranging respectively from 36.72 to $42.71 \%, 16.21$ to $19.45 \%, 14.68$ to $20.69 \%, 1.22$ to $2.00 \%$ and 75.18 to $84.13 \%$. The perennial peanut cut every 40days under the conditions of Montes Claros, Minas Gerais, Brazil showed good nutritional characteristics, and high IVDMD, suggesting its use for feeding cattle, especially in periods of scarcity of forage, because hay can be stored for long periods.
\end{abstract}

Keywords: nutritional composition, legume, forage, digestibility
Volume 7 Issue 5 - 2018

\author{
Thiago Meireles Félix,' Neide Judith Faria \\ de Oliveira, ${ }^{2}$ Luciana Castro Geraseev, ${ }^{2}$ \\ Norberto Mario Rodriguez ${ }^{3}$ \\ 'Agrarian Sciences Institute, Federal University of Minas Gerais \\ (UFMG), Brazil \\ ${ }^{2}$ Associated Professor, Agrarian Sciences Institute, Federal \\ University of Minas Gerais (UFMG), Brazil \\ ${ }^{3}$ Department, Federal University of Minas Gerais (UFMG), Brazil
}

Correspondence: Neide Judith Faria de Oliveira,Agrarian Sciences Institute, Federal University of Minas Gerais (UFMG), Av. Universitária $n^{\circ} 1000$, Bairro Universitário. Postal Box-135, ZIP CODE-39404547, Montes Claros, MG, Brazil,Tel +55 38 21017743 ,

Email neidewfmg@gmail.com, neidejwdith@hotmail.com

Received: August 09, 2018 | Published: November 13, 2018

\section{Introduction}

A. pintoi (Fabaceae and Papilionoideae subfamily) or perennial peanut is a tropical legume forage native of Brazil, tolerant of low fertility soils. Used as pasture, ground cover and as an ornament were found from North to South of the country, besides Argentina, Uruguai, Colombia, Australia and United States. ${ }^{1-3}$

Legumes have a typical foliar anatomy of the three-carbon metabolic pathway (C3) species, present higher protein content and digestibility and are recommended to increase crude protein availability to grazing animals. When compared with tropical grasses, C4 plants, possesses high protein and digestibility levels. ${ }^{2,4}$

Considering the costs of feeding in animal husbandry, to offer appropriate nutritional formulas with diversification of ingredients is essential for the animal production. ${ }^{5}$ However, only to evaluate the amount of nutrients supplied to the ruminant by the nutritional composition can be insufficient. The in vitro anaerobic incubation of the food with ruminal fluid is a valuable tool to estimate the degradability with high precision and using small amount of sample. ${ }^{6}$

To mimetize the ruminal digestion in $48 \mathrm{~h}$, the food is placed under anaerobic conditions, in contact with the ruminal liquid containing viable microorganisms, with constant temperature of $39^{\circ} \mathrm{C}$ and buffered $\mathrm{pH}$. Subsequently the digestion is done with pepsin and weak acid, for 24 hours. ${ }^{6}$ This procedure allows simulating the natural conditions of the digestion and obtaining representative and reliable results. In addition, it is possible to estimate the degradability of several samples at the same time. ${ }^{6-8}$

Despite several studies made with tropical grasses, few researches are conducted with this forage, especially in the North of Minas Gerais, Brazil. The objective of this work was to determine the nutritional composition and in vitro dry matter degradability of $A$. pinto $i$ hay.

\section{Material and methods}

The experiment was conducted in the Institute of Agrarian Sciences, in Montes Claros, Minas Gerais State, Brazil. The weather of the region is tropical wet with dry summer (As) according to the
Köppen classification. ${ }^{9}$ Were utilized five flowerbeds, with $3.99 \mathrm{~m}^{2}$ each, of $A$. pintoi cv. Belmonte previously established as a study field five years ago. The soil presented medium fertility in the laboratory analysis, with low exchangeable aluminum, high levels of potassium, phosphorus and magnesium, and a good ratio of alkaline content. The fertilizing utilized was bovine tanned manure $\left(40 \mathrm{Kg} / \mathrm{m}^{2}\right)$ in a unique use 40days before the first cut and watered daily as a field capacity.

After a cut for homogenization nine successive cuts (C) were made to each 40 days, being in 2008 June, $17^{\text {th }}$; July, $27^{\text {th }}$; September, $09^{\text {th }}$; October $16^{\text {th }}$ and November, $26^{\text {th }}$ and in 2009 January, $08^{\text {th }}$; February, $16^{\text {th }}$; April $06^{\text {th }}$ and May, $16^{\text {th }}$, denominated $\mathrm{C} 1$ to $\mathrm{C} 9$, respectively. The hay was obtained by drying in the sun on canvases, with the mixture to each hour, up to reaching the hay point less than $15 \%$ of humidity and stored in plastic woven bags. Homogeneous samples of each flowerbed and cut were collected and ground Willey mill, using mesh of $1 \mathrm{~mm}$. The samples were conditioned in plastic opaque bottles.

In the laboratory of Animal Nutrition of the department of Zootechny Veterinary School of the UFMG, in Belo Horizonte, Minas Gerais, Brazil were determined dry matter (DM), Crude protein (CP), neutral detergent fiber (NDF), acid detergent fiber (ADF), mineral matter (MM) and lignin of the samples. The sequential method 18 was utilized. For the in vitro dry matter degradability (IVDMD) was utilized an Holstein bovine, with $450 \mathrm{Kg}$ of body weight maintained in the Veterinary School of the UFMG, fed with $9 \mathrm{Kg}$ of Coast cross hay, $4 \mathrm{Kg}$ of commercial concentrate and Brachiaria (Urochloa) brizantha pasture, water, and mineral commercial supplement ad libitum. Through ruminal fistula were collected the ruminal liquid and maintained in thermos container. The protocol was approved by ethics in the use of animals committee with $n^{\circ} 42 / 2008$.

According to IVDMD modified methodology, ${ }^{10}$ samples $1,0 \mathrm{~g}$ of the cuts were weighed in duplicate, bagged in wrappings with $25 \mu \mathrm{m}$ mesh (F57 - ANKOM $\left.{ }^{\circledR}\right)$ and deposited in individual jars of the equipment $A N K O M \circledR$ (Daisy II Incubator) with the ruminal liquid. At the same time, were prepared buffer solution A and complementary solution named B. For the first solution were used $32.64 \mathrm{~g}$ of monobasic potassium phosphate $\left(\mathrm{KH}_{2} \mathrm{PO}_{4}\right)$ and $69.76 \mathrm{~g}$ of dibasic sodium 
phosphate (Na2HPO4); $12 \mathrm{~g}$ of magnesium sulfate $\left(\mathrm{MgSO}_{4} \cdot 7 \mathrm{H}_{2}\right)$ and $4 \mathrm{~g}$ of potassium chloride $(\mathrm{KCl})$. For the complementary solution $\mathrm{B}$ were used $160 \mathrm{ml}$ of anhydrous sodium carbonate solution $15.73 \%$ $(\mathrm{w} / \mathrm{v})\left(15.73 \mathrm{~g} \mathrm{Na}_{2} \mathrm{CO}_{3} / 100 \mathrm{~mL}\right), 80 \mathrm{~mL}$ of the $8 \%(\mathrm{w} / \mathrm{v})$ urea solution were used; $0.80 \mathrm{~g}$ of calcium chloride $\left(\mathrm{CaCl}_{2}\right)$ and $0.2 \mathrm{~g}$ of sodium sulfate monohydrate $\left(\mathrm{Na}_{2} \mathrm{~S}_{9} \mathrm{H}_{2} \mathrm{O}\right)$. Were added to each jar $1332 \mathrm{ml}$ of buffer A and $268 \mathrm{ml}$ of solution $\mathrm{B}$, resulting in 6.8 final $\mathrm{pH}$. After reaching $39^{\circ} \mathrm{C}$, carbon dioxide was purged to obtain anaerobiosis and after 30 minutes $400 \mathrm{ml}$ of the filtered rumen liquid was added. The jar remained in the incubator at $39.0^{\circ} \mathrm{C}$ for $48 \mathrm{~h}$ under constant stirring. After that time $8 \mathrm{~g}$ of pepsin and $40 \mathrm{ml}$ of $\mathrm{HCl}$ were added and the same incubation was carried out for another 24h. After this interval the jars were drained and the F57 wrappings were washed in distilled water at room temperature to remove residues and gas contained in that. Subsequently, they were dry at $105^{\circ} \mathrm{C}$ for $24 \mathrm{~h}$, cooled in desiccators and weighed, according to the methodology adapted. ${ }^{10}$

The data of nine cuts (treatments) and five flowerbeds (repetitions) were subjected to the variance analysis with the Statistical Analyses System. ${ }^{11}$ The averages of the cuts were compared with the ScottKnott test $(\mathrm{p} \leq 0.05)$.

\section{Results}

Table 1 describes climate variables during the experiment, obtained in a climatic station located in the Agrarian Sciences Institute in Montes Claros. The North of Minas Gerais, as can be verified in Table 1 , has two marked seasons in the year, one dry and another wet, but with few rainy months. In three months of a year were accumulated $1023.9 \mathrm{~mm}$ of precipitation, corresponding to $95.04 \%$ of the total.

Table I Average meteorological data from 2008, May to 2009, May in Montes Claros, Minas Gerais, Brazil

\begin{tabular}{|c|c|c|c|c|c|c|}
\hline \multirow[b]{2}{*}{ Period } & \multicolumn{6}{|c|}{ Temperature $\left({ }^{\circ} \mathrm{C}\right)$} \\
\hline & Minimum & Medium & Maximum & $\begin{array}{l}\text { Relative } \\
\text { humidity (\%) }\end{array}$ & $\begin{array}{l}\text { Precipitation } \\
(\mathbf{m m})\end{array}$ & $\begin{array}{l}\text { Solar radiation } \\
\left(\mathrm{W} / \mathrm{m}^{2}\right)\end{array}$ \\
\hline $05 / 07 / 2008$ to $06 / 17 / 2008$ & 20.1 & 20.5 & 20.9 & 70.5 & 0.2 & 208.8 \\
\hline $06 / 18 / 2008$ to $07 / 27 / 2008$ & 18.2 & 18.6 & 19.1 & 65.7 & 0 & 199 \\
\hline $07 / 28 / 2008$ to $09 / 06 / 2008$ & 20.6 & 21.1 & 21.6 & 55.2 & 0 & 230.8 \\
\hline $09 / 07 / 2008$ to $10 / 16 / 2008$ & 24.6 & 25 & 25.4 & 52.8 & 11.2 & 243 \\
\hline $10 / 17 / 2008$ to $11 / 26 / 2008$ & 25.4 & 25.7 & 26 & 61.8 & 196.5 & 218.7 \\
\hline II/27/2008 to $01 / 08 / 2009$ & 23.3 & 23.6 & 23.8 & 81.3 & 607.4 & 244.5 \\
\hline $01 / 09 / 2009$ to $02 / 16 / 2009$ & 25 & 25.3 & 25.7 & 69.7 & 92.8 & 322.5 \\
\hline $02 / 17 / 2009$ to $04 / 06 / 2009$ & 24.4 & 24.7 & 25 & 74.5 & 127.2 & 284 \\
\hline $04 / 07 / 2009$ to $05 / 16 / 2009$ & 22.1 & 22.4 & 22.6 & 77.5 & 42 & 268.3 \\
\hline
\end{tabular}

Temperature: in Celsius $\left({ }^{\circ} \mathrm{C}\right)$; Solar Radiation, in watts per square meter $\left(\mathrm{W} / \mathrm{m}^{2}\right)$

Source: Meteorological Station - available on: $<$ http://www.ica.ufmg.br/gemisa/index.php?option=com _content\&view=a rticle\&id=22\&ltem id=57>.Access on: 24 set. 2010

Table 2 Dates of cuts (C) with average levels (\%) of dry matter (DM), neutral detergent fiber (NDF), acid detergent fiber (ADF), crude protein (CP), mineral matter (MM), lignin (LIG), in vitro dry matter degradability (IVDMD) and coefficient of variation (CV) for the perennial peanut hays of nine successive cuts

\begin{tabular}{|c|c|c|c|c|c|c|c|c|c|c|}
\hline & \multicolumn{10}{|l|}{ Years } \\
\hline \multirow[b]{2}{*}{ Levels(\%) } & 2008 & & & & & 2009 & & & & \\
\hline & $\begin{array}{l}\text { June } \\
17^{\text {th }}\end{array}$ & $\begin{array}{l}\text { July } \\
27^{\text {th }}\end{array}$ & $\begin{array}{l}\text { September } \\
09^{\text {th }}\end{array}$ & $\begin{array}{l}\text { October } \\
16^{\text {th }}\end{array}$ & $\begin{array}{l}\text { November } \\
26^{\text {th }}\end{array}$ & $\operatorname{8}^{\text {th }}$ & $\begin{array}{l}\text { February } \\
16^{\text {th }}\end{array}$ & $\begin{array}{l}\text { April } \\
6^{\text {th }}\end{array}$ & $\begin{array}{l}M a y \\
16^{\text {th }}\end{array}$ & CV(\%) \\
\hline & $\mathrm{Cl}$ & C2 & C3 & C4 & C5 & C6 & C7 & C8 & C9 & \\
\hline DM & $90.80^{\mathrm{a}}$ & $90.60^{\mathrm{a}}$ & $91.26^{a}$ & $90.67^{a}$ & $89.85^{a}$ & $89.10^{a}$ & $90.3 I^{a}$ & $91.49^{a}$ & $91.63^{a}$ & 1.24 \\
\hline NDF & $38.12^{b}$ & $38.25^{b}$ & $36.95^{b}$ & $36.72^{b}$ & $39.5 \mathrm{I}^{\mathrm{a}}$ & $41.14^{a}$ & $39.98^{\mathrm{a}}$ & $40.79^{a}$ & $42.7 I^{a}$ & 7.44 \\
\hline ADF & $16.85^{c}$ & $|7.1|^{c}$ & $\left.16.2\right|^{c}$ & $16.70^{c}$ & $17.66^{\mathrm{b}}$ & $19.45^{\mathrm{a}}$ & $19.10^{a}$ & $\left.17.9\right|^{b}$ & $17.87^{b}$ & 4.88 \\
\hline $\mathrm{CP}$ & $20.49^{a}$ & $20.03^{a}$ & $20.69^{a}$ & $20.49^{a}$ & $\left.18.5\right|^{b}$ & $15.60^{\circ}$ & $14.68^{c}$ & $17.73^{b}$ & $17.96^{\mathrm{b}}$ & 5.57 \\
\hline MM & $1.73^{\mathrm{a}}$ & $2.00^{\mathrm{a}}$ & $1.78^{\mathrm{a}}$ & $1.76^{\mathrm{a}}$ & $1.86^{\mathrm{a}}$ & $1.75^{\mathrm{a}}$ & $1.52^{\mathrm{b}}$ & $1.22^{\mathrm{b}}$ & $1.33^{\mathrm{b}}$ & 17.35 \\
\hline LIG & $3.10^{\mathrm{a}}$ & $2.98^{\mathrm{a}}$ & $3.17^{\mathrm{a}}$ & $2.43^{a}$ & $3.87^{\mathrm{a}}$ & $3.30^{\mathrm{a}}$ & $3.32^{\mathrm{a}}$ & $3.77^{\mathrm{a}}$ & $3.87^{\mathrm{a}}$ & 23.57 \\
\hline IVDMD & $83.33^{\mathrm{a}}$ & $81.81^{a}$ & $84.13^{a}$ & $80.94^{a}$ & $82.26^{\mathrm{a}}$ & $76.92^{b}$ & $75.18^{b}$ & $76.29^{b}$ & $78.29^{b}$ & 3.35 \\
\hline
\end{tabular}

${ }^{a}$ Averages followed by different lowercase letters in line differ by Scott-Knott test $(p \leq 0.05)$. Results expressed in dry matter basis

Table 2 demonstrates the nutritional composition and degradability of A. pintoi hay, with DM similar in all cuts. The NDF ranged $(\mathrm{p} \leq 0.05)$ between 36.72 in 2008 , October to $42.71 \%$ in 2009 , May. From November to May NDF were statistically significant higher demonstrating the growing of this tropical plant in the wet months, favoring the stems elongation.

The mean values of ADF were different $(p \leq 0.05)$ between the cuts, being 16.21 in 2008 , September to $19.45 \%$ in 2009, January. The lower levels of ADF occurred from June to October ( $\mathrm{C} 1$ to $\mathrm{C} 4)$, considered dry months. In this research seems that precipitation was the limitation factor to $A$. pintoi growth.

The CP averages oscillated $(\mathrm{p} \leq 0.05)$ from 14.68 in 2008, September to 20.69 in February, 2009. As ADF, the lower levels of $\mathrm{CP}$ occurred in dry months (C1 to $\mathrm{C} 4)$. Probably the lesser growth 
supports the leaves accumulation, and in this part of the plant were accumulated nitrogen compounds like amino acids.

For the MM, the averages were 1.22 to $2 \%$ (Table 2 ), and $\mathrm{C} 1$ to C6 showed higher means $(\mathrm{p} \leq 0.05)$, corresponding from 2008, June to 2009, January. Probably the successive cuts can reduce the plant mineral stores in C7, C8 and C9. The lignin averages were similar in all cuts, but have to be considered the elevated variation coefficient of the methodology.

IVDMD showed mean varying from 75.18 in February, 2009 to $84.13 \%$ in 2008 , September and in $\mathrm{C} 1$ to $\mathrm{C} 5$ was higher $(\mathrm{p} \leq 0.05)$ than other cuts. These values were corroborated by lower NDF means from June to October making the perennial peanut hay more degradable by ruminal fluid in these cuts.

\section{Discussion}

The meteorological data confirms the historical values described in the North of Minas Gerais1, Brazil. And can influence the tropical plant growing physiology and consequently modify the nutritional components. The DM averages ranged from 89.1 to $91.6 \%$ (Table 2) and corroborate MS values $88.70 ; 88.10$ and $92.80 \%$ reported for perennial peanut hays. ${ }^{2,7,12}$ Normally to be considered a hay foodstuff, it DM can be below $15 \%$ in order to avoid damage microorganisms proliferation. ${ }^{10,13}$ Considering only the DM (Table 2) the A. pintoi hay can be a forage source without contamination problems, if the storage conditions were adequate.

The greatest averages of the NDF (Table 2) have been verified rainfall period with higher solar radiation incidence and elevated temperatures (Table 1), thereby contributing to greater growth of the legume and consequently favoring the stems elongation. So the stem: leaves relation increased and is reflected in fiber containing. Tropical forages develop more in rainy season; consequently can contain higher concentration of fiber in this period..$^{5}$ These results of NDF (Table 2) are close to or lower than those $43.4 ; 46.8 ; 51.60 ; 52.50$ and $55.50 \%$ achieved in $A$. pintoi with $60,70,100$, and 42days, respectively ${ }^{1,2,7,14,15}$ and to the $44 \%$ obtained in Arachis glabrata. ${ }^{16}$

The mean values of ADF (Table 2) were lower than the 33.6, 28.1, 34.8, 35.8 and 30.7 described to forage legumes between 40 to 100days of age. ${ }^{1,2,7,14,15} \mathrm{~A}$. pintoi partially dehydrated and as silage presented ADF of 36.4 e $39 \%$, respectively. ${ }^{17}$ The ADF of 43.7, 32.9, 33.3 and $28.5 \%$ was described in forage legumes Medicago sativa, Desmodium ovalifolium, Stylosanthes guianensis and Cajanus cajan. ${ }^{18}$ The fibers rising could be related to morphological chemical changes occurred with the growth of the plants and decrease the nutritional ideal compounds like protein and soluble carbohydrates. Increased deposition of cell wall also reduces the intake and digestibility of foodstuff, being undesirable. ${ }^{15,18}$ So the lower content of ADF (Table 2) could indicate a good nutritive value, because when the plant accumulates cell wall the cytoplasmic area is reduced..$^{15}$

The $\mathrm{CP}$ was higher $(\mathrm{p} \leq 0.05)$ in the $\mathrm{C} 1$ to $\mathrm{C} 4$ of $A$. pintoi hays (Table 2). In dry season the plants showed lower fiber content (Table 2). CP tends to elevate when the tropical plant legume grown less, because the leaves concentrate more amino acids with high biological value in consequence of the climate, as can be verified in Table 1. In same way the greater growth of the tropical forage in the summer favors the accumulation of the cell wall and CP tends to reduce. ${ }^{8}$ So the relation stem: leaves increase in wet season and the levels of $\mathrm{CP}$ tend to reduce in flowering and mature plants. The $\mathrm{CP}$ averages (Table 2) are close to $20.80,14.30$ and $18 \%$ described to perennial peanut., ${ }^{2,15}$ Several Arachis spp. genotypes show CP of 21.30 or $21.60 \%{ }^{3,14}$ and this legume silage, $21.62 \% .{ }^{17}$ When grown with different levels of fertilization and liming, $\mathrm{CP}$ up to $26.2 \%$ was described in $A$. pinto ${ }^{19}$ reinforcing that the successive cuts can decrease the protein content of the plant. Furthermore, these variations can be explained by the experimental conditions, because at the present work only one fertilization were made 40days before the first cut and it can be reflected in soil nitrogen and plant protein storages being consumed with the successive cuts.

For the MM, the averages were are lower than the 9.10; 10.90 and $10.20 \%{ }^{7,14,17}$ The lignin average of $A$. pintoi ranged from 2.43 to $3,87 \%$ and the results are below of $7.60 ; 4.90$ and $11.20 \% .^{2,14,20}$ These variations can be explained by the different experimental methods of analyses adopted by authors, diverse cultivation practices, plant ages and other conditions as fertilization between experiments.

Even the less value of $A$. pintoi IVDMD in this experiment (Table 2) was superior to $71,72.3$ and 72.4 or $67.1,67.7$ and $67.3 \%$ in two successive cuts every 34 days in the rainy season, with cutting heights of $1.0 ; 5.0$ and $10 \mathrm{~cm}$, respectively. ${ }^{19}$ Other experiment reported IVDMD between 61.2 the $67.8 \%$ obtained for the same forage. ${ }^{4} \mathrm{~A}$. pintoi and Arachis repens cultivated and cut at every 42days showed IVDMD of 69.30 and $70.60 \% .^{14}$ The perennial peanut in situ digestibility of the DM was $83.70 \%$ in horses, ${ }^{16}$ value that approaches to the maximum value of ruminal in vitro degradability obtained in this work (Table 2). These variations can be explained by the different methods and species used, plant ages and other experimental conditions as plant fertilization and cutting age or height.

Tropical forages have fibrous constituents negatively correlated with the digestibility, ${ }^{6}$ in this way, the high IVDMD is related to the reduced levels NDF and ADF as exposed in Table 2. The lowest digestibility comes to thickening the cell and the thickness of the walls lignified, increasing the non digestible fiber. ${ }^{8}$ Legumes are generally more digestible when compared to grasses, because they have less content of cell wall and a typical foliar anatomy of the three-carbon metabolic pathway (C3) species, present higher protein content and digestibility. ${ }^{16}$ Thus, the lowest averages of the IVDMD between the C6 to $\mathrm{C} 9$ are justified by higher levels of the FDN (Table 2) associated to the favorable climate (Table 1) contributing to the increased growth of tropical plants, like the perennial peanut. ${ }^{21}$

\section{Conclusion}

The A. pintoi hay cultivated in a year in the North of Minas Gerais, Brazil has high content of CP, small NDF and ADF and elevated in vitro dry matter degradability. This legume can be used as an option to ruminants ensuring favorable nutritional composition and digestibility.

\section{Funding details}

This experiment occurred with resources from the researchers and the structure of Agrarian Sciences Institute, Veterinary School and Federal University of Minas Gerais, that the authors are grateful.

\section{Acknowledgements}

To Capes - Coordenação de Aperfeiçoamento de Pessoal de Nível Superior - Coordination of Improvement of Personnel of Superior Level.

\section{Conflict of interest}

Authors declare that there is no conflict of interest. 


\section{References}

1. Baptista CRW, Moretini CA, Martinez JL. Arachis pintoi palatabilidade, crescimento e valor nutricional frente ao pastoreio de equinos adultos. Revista Acadêmica. 2007;5(4):353-357.

2. Gobbi KF, Garcia R, Garcez Neto AF, et al. Características morfológicas, estruturais e produtividade do capim-braquiária e do amendoim forrageiro submetidos ao sombreamento. Rev Bras Zootec. 2009;38(9):1645-1654.

3. Ladeira MM, Rodriguez NM, Borges I, et al. Avaliação do feno de Arachis pintoi utilizando o ensaio de digestibilidade in vivo. Rev Bras Zootec. 2002;31(6):2350-2356.

4. Fernandes, GM, Possenti RA, Teixeira de Mattos W, et al. In situ degradability and selected ruminal constituents of sheep fed with peanut forage hay. Arch Anim Nutr. 2013;67(5):393-405.

5. Morgado ES, Almeida FQ, Silva VP et al. Digestão dos carboidratos de alimentos volumosos em equinos. Rev Bras Zootec. 2009;38(1):75-81.

6. Van Soest PJ. Nutritional ecology of the ruminant. 2nd ed. New York: Cornell University Press; 1994.

7. Fernandes GM. Degradabilidade in situ e parâmetros ruminais de ovinos alimentados com feno de Arachis pintoi cv. Belmonte. 2012.

8. Silva DJ, Queiroz AC. Análise de alimentos (método químico e biológico). 3rd ed. Viçosa, UFV; Imprensa Universitária; 2002. 235 p.

9. Alvares CA, Stape JL, Sentelhas PC, et al. Köppen's climate classification map for Brazil. Meteorologische Zeitschrift. 2013;22(6):711-728.

10. Campos FP, Nussio CMB, Nussio LG. Método de análise de alimentos. Piracicaba: FEALQ; 2004. 135 p.

11. Paulino VT, Bueno MS, Abdalla AL. Composição química e compostos fenólicos em Arachis pintoi 'belmonte'. Archivos de Zootecnia. 2012;61(236):611-614.

12. Menezes APM, Assis GML, Mataveli M, et al. Genetic divergence between genotypes of forage peanut in relation to agronomic and chemical traits. Rev Bras Zootec. 2012;41(7):1608-1617.
13. Silva VP, Almeida FQ, Morgado ES, et al. Digestibilidade dos nutrientes de alimentos volumosos determinada pela técnica dos sacos móveis em equinos. Rev Bras Zootec. 2009;38(1);82-89.

14. Fernandes DF, Carvalho MA, Andrade RP, et al. Avaliação agronômica de acessos de Arachis spp. Boletim de Pesquisa e Desenvolvimento 108 - Embrapa Cerrados. Brazilian Agriculture Research CorporationEmbrapa. 2003:5-11.

15. Silva VP, Almeida FQ, Morgado ES, et al. In situ caecal degradation of roughages in horses. Rev Bras Zootec. 2010;39(2):349-355.

16. Eckert JV. Digestibility and nutrient retention of perennial peanut and bermudagrass hays for mature horses. Master's Thesis, Dept. of Animal Sciences. Gainesville: University of Florida Institute of Food and Agricultural Sciences. 2008

17. Padua FT, Almeida JCC, Silva TO, et al. Produção de matéria seca e composição químico-bromatológica do feno de três leguminosas forrageiras tropicais em dois sistemas de cultivo. Ciência Rural. 2006;36(4):1253-1257.

18. SAS - INSTITUTE INC. Base SAS ${ }^{\circledR} 9.4$ Procedures Guide. Cary-NC: SAS Institute Inc; 2011.

19. Paulino VT, Ferrari Júnior E, Rosan AP, et al. Silagem de amendoim forrageiro (Arachis pintoi cv. Belmonte) com diferentes aditivos. Bol Ind Animal. 2009;66(1):33-43.

20. Ferreira AL. Divergência nutricional em genótipos de amendoim forrageiro (Arachis spp.). Dissertação (Nutrição e Alimentação Animal) - Escola de Veterinária. Belo Horizonte: Universidade Federal de Minas Gerais; 2010. 45 p.

21. Velásquez PA, Berchielli TT, Reis RA, et al. Composição química, fracionamento de carboidratos e proteínas e digestibilidade in vitro de forrageiras tropicais em diferentes idades de corte. Rev Bras Zootec. 2010;39(6):1206-1213. 